\title{
Europa, sempre às quartas
}

\author{
Europe, always on Wednesdays
}

Myriam Correa de Araujo Ávila

Universidade Federal de Minas Gerais (UFMG), Belo Horizonte / Brasil

Doutorado em Literatura Comparada, UFMG myriavila@gmail.com

Tradução do texto de Detlev Claussen, sociólogo, especialista em Teoria Crítica e dedica-se, entre outros temas, ao estudo da sociologia do futebol. Autor, no Brasil, de Bela Guttmann: uma lenda do futebol do século XX, Estação Liberdade, 2014.

A Europa nasceu numa quarta-feira. A Europa emergiu à luz dos holofotes dos jogos noturnos dos anos 50 e 60. Era uma Europa maior do que permitia a Guerra Fria. A equipe de futebol húngara Honvéd, com sua grande estrela Ferenc Puskás, jogou durante o levante da Hungria de 1956 em Bilbao, por ocasião da Copa Europeia dos Campeões. Depois das humilhações impostas a eles pelos cartolas húngaros após a derrota para a Alemanha na final da Copa do Mundo em Berna e das ações punitivas populistas do Partido Comunista que comandava a Hungria, o USAP, a maioria dos jogadores preferiu permanecer na Europa Ocidental. Apesar do comportamento mesquinho da UEFA, a liga futebolística europeia, que suspendeu os fugitivos durante dois anos, os jogadores conseguiram ingressar nos melhores times do lado ocidental, passando a jogar contra equipes do bloco oriental. Esses jogadores talentosos tornaram-se amados tanto no lado ocidental como no oriental. A Europa se tornara, para além das querelas políticoestatais, uma imagined community (Benedict Anderson). 
Essa coesão imaginária fortaleceu-se por meio da introdução generalizada da televisão a partir de 1958 - "Eurovision" era a palavra mágica, seguida por um imponente hino. Na Copa do Mundo da Suécia, em 1958, a Eurovision estava presente em todos os jogos. A Alemanha estava pronta para o mundo; mas não para a Europa. Depois de perder para a Suécia na semifinal em Göteborg, turistas suecos na Alemanha tiveram seus pneus furados durante a noite. Acusavam-se os suecos de terem apoiado sua seleção por megafones com gritos de "Heja, heja, Sverige" - enquanto os alemães engoliam pacientemente de Michel a expulsão de Juskowiak, que agredira violentamente o "mercenário" Hamrin. A Alemanha, novamente vítima da insídia românica! Como era possível? O louro sueco Kurt Hamrin jogava, como alguns outros suecos, com sucesso no futebol italiano por dinheiro; era carinhosamente chamado pelos tifosi ${ }^{1}$ "uccelino" (passarinho). A Alemanha naquela época apegava-se ainda ao status de amador, ou melhor, a um amadorismo aparente.

Somente após a decepção de 58 na Suécia, os jogadores alemães começaram também a emigrar para a Itália: com Albert Brülls und Helmut Haller iniciou-se uma nova Viagem à Itália. ${ }^{2}$ Os louros alemães tornaram-se imediatamente populares entre os italianos; a velha expressão "panzer tedeschi"3 perdeu a força. "Justamente o Schnellinger!" que em 1970 na semifinal contra a Itália no estádio asteca do México fez o gol de empate durante os minutos de prorrogação do segundo tempo, civilizou as relações entre os dois eternos rivais. O louro KarlHeinz Schnellinger jogou pelo Milan com Kurt Hamrin em um time do qual ainda fazia parte Giovanni Trappatoni, que foi igualmente de importância decisiva para a boa convivência ítalo-germânica. Cada vez mais alemães iam para a Itália, não apenas como turistas. Jogadores louros como Klinsmann e Brehme tornaram-se Interistas. Vindo de um subúrbio de Frankfurt, Andy Möller, que em Turim aprendeu a falar fluentemente o italiano (sua segunda língua estrangeira depois do

\footnotetext{
${ }_{1}^{1}$ Palavra italiana para torcedores (NT).

${ }^{2}$ Referência ao livro de Goethe (NT).

3 "Tanques de guerra alemães" (NT).

${ }^{4}$ Ausgerechnet Schnellinger! (Justamente o Schnellinger) tornou-se uma expressão cult, criada pelo locutor que narrava o jogo contra a Itália na Copa de 1970 e refere-se ao fato de que ele jogara na Itália durante anos (NT).
} 
Hochdeutsch), ${ }^{5}$ foi direto ao ponto: "Milão ou Madri, dá na mesma - desde que seja Itália!" Uma noção solidária de Europa que não se detém nas fronteiras nacionais.

A Liga dos Campeões, uma invenção dos anos 50 de pessoas com muita experiência de migração, que lamentavam o fim da antiga Copa da Europa Central (Mitropa), a qual nascera do futebol do Danúbio, tornou a Europa uma realidade. Os fundadores queriam apenas ganhar dinheiro. Não é preciso jogar só nos fins de semana, pode-se jogar também às quartas-feiras. Sempre às quartas. A Liga dos Campeões leva adiante essa tradição. Talvez o meu time não tenha se classificado; mas outros times de minha preferência continuam jogando. Assim, começo o campeonato nacional com o Werder Bremen (que, no momento, não chega aos jogos internacionais), depois passo a torcer pelo Arsenal (já que os exWerderianos Özil e Mertesacker estão jogando lá agora). Se não der certo, apelo para o Barcelona por causa do futebol ofensivo e dos meus queridos latinoamericanos Messi e Neymar. Se tudo der errado, sobra ainda o ex-treinador do Barcelona Pep Guardiola, do qual eu, notório adversário do Bayern, ainda posso dizer - se jogarem tão bem quanto o Barça jogava, vá lá. O que é bom na Europa pode até mesmo contribuir para aplacar uma feroz inimizade na Alemanha.

Com a Liga dos Campeões, a festa futebolística europeia saída da Copa Europeia das Nações amplia-se e eterniza-se. Hoje todo o miolo da semana, de terça a quinta, pertence à Europa. Começou com a Copa da Europa, que mesmo os de fora podiam ganhar. Foi o que provou Béla Guttmann com o Benfica de Lisboa, que bateu as então dominantes equipes espanholas FC Barcelona e Real Madrid. Espanholas? No Real detinham o cetro nos anos 50 e 60 Alfredo di Stéfano e Ferenc Puskás. Alfredo di Stéfano, batizado pelos fãs carinhosamente El Alemán, tinha abandonado a Argentina após uma greve dos jogadores contra os baixos salários. Segundo a vontade do patriarca Santiago Bernabéu dividia o meio de campo ofensivo com o húngaro Ferenc Puskás, que após a fuga da Hungria encontrara um novo lar em Madri. Na ala esquerda driblava o francês descendente de mineiros poloneses Raymond Kopa. Na esquerda corria Paco Gento, la Galerna del Cantábrico, o furacão da Cantábria. 0 Real também não tinha só madrilenhos.

\footnotetext{
${ }^{5} \mathrm{O}$ alemão culto, nem sempre a primeira língua do cidadão da Alemanha (NT).
} 
Nem o arquirrival catalão Barcelona fazia questão de se opor ao Real pela pureza étnica. Do Time de Ouro húngaro trouxeram Zoltán Czibor e o artilheiro da Copa do Mundo de 54 Sándor Kocsis. 0 último tornou-se na capital catalã o Cabeza d'Oro, por causa de suas bolas de cabeça. Ambos eram dirigidos pelo também disputado por Madri László Kubala, também chamado Ladislao, Ladislav e Ladislaw. Ele foi em uma única pessoa a encarnação precursora da Europa de hoje. Filho de uma família de pedreiros eslovaco-polonesa, nascido na Hungria, conseguiu autorização para jogar pela Tchecoslováquia e pela Hungria; mas de fato só se aclimatou de vez como jogador e treinador na Espanha. Ele próprio se intitulava cidadão do mundo. Isolados no topo tornaram-se os - como diriam hoje os sociólogos - times transnacionais do Benfica. A estrela do time era um certo Eusébio, que cresceu em Moçambique jogando no time de rua Os Brasileiros. 0 campeonato europeu trouxe o mundo para a Europa e, com a televisão, ele entrou na sala de cada casa. A Europa hoje não consiste apenas na Liga dos Campeões, e sim a antiga Messestädtepokal, a Copa da UEFA, transformou-se na Euro-Liga, meta possível também para os times de província. É o turismo do futebol que primeiro viabiliza essa Europa. Com incrível entusiasmo, as equipes são acompanhadas pelos torcedores nos jogos fora de casa. A Europa se tornou um centro de gravitação do futebol mundial - todos querem em pleno meio da semana participar dele, mesmo que seja apenas pela TV. 